\title{
Kršćanske poruke u pismima sv. Jeronima
}

\author{
Drago TUKARA* \\ • https://doi.org/10.31823/d.28.4.8 • \\ UDK: 27-9 Hieronymus, sanctus • Stručni članak \\ Primljeno: 18. lipnja 2020. Prihvaćeno: 2. prosinca 2020.
}

Sažetak: Ovaj članak nastaje povodom 1600 godina od smrti sv. Jeronima, a bavi se Jeronimovim pismima, odnosno nekim kršćanskim porukama u tim pismima. U prvom dijelu svetac stavlja naglasak na izgradnju vlastite osobnosti i odnosa prema Bogu. Kao zaljubljenik u Sveto pismo Jeronim se ispovijeda pred Bogom; susreće Boga u svojoj nutrini i u tumačenju Svetoga pisma, a svi oni koji su lijeni upoznati Boga i tajnu Riječi podvrgnuti su njegovoj kritici. Drugi dio rada bavi se isticanjem medusobne suradnje unutar crkvene zajednice, ponajprije medu svećenicima, đakonima, monasima. U tom kon-

${ }^{*}$ Doc. dr. sc. Drago Tukara, Katolički bogoslovni fakultet u Đakovu Sveučilišta J.J. Strossmayera u Osijeku, Petra Preradovića 17, p. p. 54, 31400 Đakovo, Hrvatska, drago.tukara@ gmail.com tekstu vrijednost prijateljstva $i$ čuvanje mira unutar crkvenih službenika prevažna je tema za Jeronima. Treći dio posvećen je dostojanstvu i ulozi žene. Činjenica je da su Jeronimov život $i$ djelovanje obilježeni komunikacijom sa ženama. To su prije svega udovice, monahinje, djevojke, majke, supruge, bogate $i$ ugledne rimske građanke. Autor u radu želi istaknuti kako se iz svih Jeronimovih korespondenata, izravno ili neizravno, jasno ili zatamnjeno, zrcale kršćanske poruke netom spomenute.

Ključne riječi: Bog, sv. Jeronim, pisma, kršćanske poruke, crkveni službenici, žene.

\section{Uvod}

Život i djelo sv. Jeronima obilježili su život Crkve od početaka pa kroz sljedeća stoljeća. Jeronimov životni opus poznat je kulturnim, društvenim, znanstvenim i biblijskim krugovima; s jedne strane njegova intelektualna i kulturna dimenzija privlače pozornost onih koji žele više znati u korist svoga naravnoga razuma i sposobnosti, a s druge 
strane njegova tipično ljudska i kršćanska narav ne ostavlja ravnodušnim one koji žele slijediti Krista Gospodina. Životni put sv. Jeronima jest put razuma i put vjere. U ovoj godini, kada se puni 1600 godina od njegove smrti, ovim radom želimo s njim prohodati barem jedan dio njegova puta, a to je put dopisivanja.

Posjedujemo lijep broj sačuvanih Jeronimovih poslanica, one su trezor iz kojega uzimamo ponajbolje blago iz njegova života. Pristup njegovim pismima/poslanicama nije s naše strane znanstveno-istraživački u strogom smislu riječi, on je više kršćansko-humanistički. To potonje nas više zanima jer jedan od osnovnih elemenata ljudskoga bića koje se ostvaruje i razvija jest riječ, ali isto tako pisana riječ jedan je od načina komuniciranja u humanom društvu. Pisana riječ postala je i Božja riječ. U njoj leži pokretačka i stvaralačka snaga. U Jeronimovoj pisanoj riječi, pismima, nalazi se dovoljno velik broj sugovornika preko kojih se mogu iščitavati kršćanske poruke.

Tko su Jeronimovi adresati? Naša je nakana predstaviti ih. U kojem su području živjeli? Želja nam je prikazati ga. Jeronim je glavni akter, a svi drugi mogu doprinijeti boljem upoznavanju njegova rada i njegove osobnosti. Status njegove obitelji, njegovo školovanje diljem gotovo čitavoga Rimskoga Carstva, njegova erudicija, sva njegova putovanja, a iznad svega njegova narav i želja za traženjem Istine bili su plodno tlo za nova (ne)prijateljstva.

Prateći Jeronimov put dopisivanja, istaknut ćemo samo neke kršćanske poruke, kao što su izgradnja vlastite osobnosti i odnosa prema Bogu, razvijanje suradnje s drugima unutar crkvene zajednice te promicanje dostojanstva i uloga žene. Na svoj jedinstven način, izravan ili neizravan, sv. Jeronim piše o tim i drugim kršćanskim porukama svećenicima, đakonima, monasima i ženama. Sam Jeronim u sebi nosi i prenosi kršćansku poruku utemeljenu na vlastitoj naravi koja je prijateljska i nagla, milosrdna i provokativna, kršćanska i poganska, duhovna i razumna.

Jeronim je tijekom svojih putovanja diljem Zapadnoga i Istočnoga Rimskoga Carstva susretao mnoge ljude s kojima je kasnije započeo svoje dopisivanje. U zapadnom dijelu Rimskoga Carstva značajniji gradovi u Jeronimovu životu jesu Rim, Akvileja i Stridon. I komu god da je pisao i u kojem god smjeru njegove poslanice išle, nezamislivo je da bi ih pisao bez Pisma i bez duha, da bi ih pisao neprijateljima bez ljudskosti i odgovarao bez kritike. I konačno, neshvatljivo je da bi kritizirao bez ljubavi.

\section{Izgrađivati vlastitu osobnost i odnos prema Bogu}

\subsection{Osobnost SVetoga Jeronima}

U osobnosti sv. Jeronima krije se sinteza, na svoj način originalna i jedinstvena: intelektualna ozbiljnost $\mathrm{i}$ emotivna strastvenost. $\mathrm{U}$ njemu postoje težnje koje $\mathrm{u}$ sebi mogu biti oprječne, na prvi pogled čini se da mu je osobnost nepovezana i 
nedosljedna. Iako je svaka osobnost enigma za drugoga, za Jeronimovu osobnost ipak bismo mogli reći da mu je najvažnija bila želja obuzdati se na mudar način, a mudrost pripada božanskoj sferi i tko bi ju htio postići, mora sebe kao takvoga predati Gospodinu i onda od Boga biti zaposjednut. U ovom izrazu želje očito je važno: istovremeno napuštanje samoga sebe i ulaganje određenoga napora: udovoljiti Božjoj inicijativi i nju slijediti vlastitom inicijativom. Ne na pasivan niti na pelagijanski način. Odnos s Bogom isključuje u čovjeku svaku ispraznost, a potiče na dinamizam koji je polet duše i postojanost karaktera.

Za Jeronima ujedinjenje s Bogom ne podnosi nikakvu slabost ili smalaksalost; moglo bi se reći da mu je velika radost čuti da se njegovi bore po Kristu. To je za njega ideal do kojega je strogo držao, do mjere da je prelazio u agresivnost, nikada hraneći popustljivost. Borio se za sebe protiv onih koji su o njemu širili kritike ili poduzimali kakve crkvene pothvate protiv njega. Borio se za jedan strog i ozbiljan asketizam, protiv svih onih koji su kršili praktični moral povezan $\mathrm{s}$ licemjerstvom i sa svjetskom slavom.

Borio se za pravo poznavanje Božje riječi, protiv neznalica i lakoumnih, za pravovjerje protiv heretika, za jedno potpuno i cjelovito prianjanje uz Boga, protiv svih onih koji su izdali Riječ Božju popuštajući niskim požudama. Borio se slijedeći svoj temperament, po kojem je izgarao da se potpuno preda Kristu: uvijek razmišljajući o biti svećeničkoga i monaškoga života, držeći se ispravnoga Kristova puta, naglašavao je da se potpuno dao Bogu tko je sebe prikazao Bogu.

Potiče da se ne daruje samo novac Bogu nego se treba darovati samoga sebe; nalaže da se siromašnoga (gologa) Krista treba slijediti siromašno (golo). U studiranju Svetoga pisma usmjerio se na istinu protiv varke. Vodio je silovite filološke rasprave oko hebrejskoga teksta, s velikom ozbiljnošću izučavao je Riječ Božju služeći se elegantnim i ukrasnim figurama s osnovnim ciljem otkriti istinito. Zapravo, nije laskao ili popuštao kada je Riječ Božja u pitanju. Radije je upozoravao na poteškoće i moguće posljedice nego dijelio neke isprike.

Kroz svoje poslanice govori o sebi, iskreno i neposredno, ali isto tako i o drugima koje voli i o onima koji mu nisu mili.

Stojeći pred riječju Božjom, bio je sav usmjeren na nebesku poruku: papi nije dijelio nikakve komplimente: divljenje je za njega boriti se protiv bilo kakvoga dodvoravanja, izabire oštar put dijaloga svaki put kada je uvjeren da se nalazi na suprotnoj strani u razmišljanjima. Takav stav dovodio ga je do čina ruganja protivnicima. Dosljedan sebi i kad se našao u burnim trenutcima.

Našavši se protiv klevetnika njegova propovijedanja o asketizmu, Jeronim nije obarao glavu, štoviše, nastupao je s odrješitom polemikom. Progone i osude koje je 
doživljavao smatrao je prigodom da posveti vlastiti duhovni život (integritet duha). Nastojanje da se ponizno ponaša dovodi do uzdizanja svoga prijestolja. Dobro se postavio naspram kulturnih potreba svoga vremena, naspram raširenih moralnih krivudanja te naspram svoje stroge savjesti. U njegovim se riječima nalazi iskrenost i ponos koji dovode do polemike.

Jeronimov lik jest zanimljiv. Njegova snaga i blagost bile su zavijene ljuskom urođene grubosti, ispod koje se nalazi potreba za iskrenošću, čiji su se gorljivo vrući temperament $\mathrm{i}$ žarka vjera znali pregrijati. Njegova se agresivnost temeljila na korijenima njegova monaškoga asketizma i na strogom studiranju egzegeze koje je težilo doći do izvora - originala. Nije bio uvijek spreman zakočiti, ali njegov motor bili su velikodušnost, pravac, plemenitost. Pretjerane reakcije pridonosile su njegovoj osjetljivoj naravi koja još nije bila dovoljno pokorena. Živio je pod velikim utjecajima koji su zasigurno zahtijevali duhovnu veličinu koja nije dopuštala kompromise, ti su utjecaji isto tako zahtijevali sveti karakter koji se treba uzdići iznad svih dvoličnosti. Težio je prema svetosti, želio je jednostavno biti čovjek, snažan i odlučan. ${ }^{1}$

Kako smo već spomenuli, Jeronim je imao prilično veliki broj osoba s kojima se dopisivao. Bilo je to prije svega njegovo odgovaranje na postavljene upite o aktualnim temama njihova vremena i nisu adresati saznavali samo pravilno tumačenje biblijskih mjesta i asketskih trenutaka nego su mogli saznati i tko su oni u svom življenju i pozivu. Osim toga Jeronim je na taj način otkrivao i samoga sebe, svi su se zrcalili pod njegovim perom. Kakav je bio Jeronimov odnos prema Bogu otkrivamo u nekoliko pisama u sljedećim dijelovima.

\subsection{VJERA U Boga}

Jeronim se našao pred problemom tuđega preljuba. Prijatelj Inocencije zamolio ga je 384. godine, dok su bili u Antiohiji, da se upusti u tumačenje nemiloga događaja u sjevernoj Italiji u kojem je žrtva postala nepravedno optužena djevojka. Ući u taj problem, kao i u onaj o nevinom progonu pravednih, za Jeronima je isto kao kormilariti teretnom lađom kroz tjesnace, dok je lađa gonjena pjenastim valovima i vodenim strujama. U taj kontekst smješta svoju malu rječitost koja može imati uspjeha ako ga prati snaga Duha Svetoga, u koju se pouzdaje. Sebe drži za kormilara koji može biti pritiješnjen suprotnim strujama, može mu nedostajati potrebnih vješti-

\footnotetext{
${ }^{1}$ Korisna literatura za bolje upoznavanje osobnosti sv. Jeronima: F. TRISOGLIO, Note stilistiche sull'epistolario di Girolamo, u: Vetera Christianorum 30(1993.), 267-288.; ISTI, La personalità di san Girolamo attraverso l'epistolario, u: La scuola Cattolica 120(1992.), 575-612.; C. CATELLANI, Immagini di »servi« nell'epistolario di s. Girolamo, u: Studia Patavia 39(1992.)3, 73-84.; ISTI, Il buon uso delle ricchezze nell'epistolario di san Girolamo, u: Cristianesimo nella storia 13(1992.), 47-72; A.CERESA-GASTALDO, Figure e motivi femminili nell'epistolario di Gerolamo, u: Orpheus 13(1992.), 77-83.
} 
na, ali u njemu uvijek postoji dobra volja za plovidbom i vjera u Boga. ${ }^{2}$ A prijatelj Rufin omogućio mu je iskustvo Božjega darivanja koje je doživio u sebi samome, a iskustvo je da Bog daruje i više nego što traži. Posuđivao je papir za pisanje samo da bi bio i na taj način bliz onima koji su boravili u pustinji, za kojom je i sam čeznuo. Zahvalan je Bogu za svakoga koji se odlučio živjeti kao monah, što je vidljivo iz govora o prijatelju Bonosu koji se nastanio na jednom otoku u Jadranskom moru: $\gg$ Hvala tebi, Gospodine Isuse, što imam onoga koji će ti se u dan tvoj za mene moliti. $\ll^{3}$

\subsection{SusRet S Bogom}

Jeronim Eustohiji svjedoči da je imao susret s Bogom u trenutku kad mu se tijelo već ohladilo, zamrlo, a duša bijaše još topla. Moglo bi se reći da se susret dogodio u posebnom stanju, u trenutku kliničke smrti. Doveden je pred Božju sudačku stolicu gdje je bila velika svjetlost i jasnost koja je izlazila iz onih koji su stajali uokolo sudačke stolice. Nije smio pogledati, bacio se dolje i tada je začuo pitanje tko je on. Odgovor mu je bio da je kršćanin, što nije prihvaćeno kao pozitivno jer je točan odgovor glasio da je ciceronijanac, a ne kršćanin. Sam piše da je molio smilovanje Božje i oni oko Božje sudačke stolice molili su da Jeronimu oprosti Bog grijehe mladosti, da mu dade još vremena da može činiti pokoru. To njegovo svjedočanstvo nije tlapnja ni varka, kaže sam Jeronim, već parnica s Bogom, nakon čega je s ljubavlju prionuo uz božanstvene knjige. ${ }^{4}$

\subsection{Plod susreta s Ruječju Božjom}

Bilo je i neprijatelja koji su Jeronimu predbacivali, štoviše, kritizirali su njegov rad na Bibliji. O tome je već pisao u nekoliko navrata, ali ima potrebu opravdati se i pred Marcelom žaleći se kako ga neki »čovuljci« rado napadaju. Ti čovuljci drže da je Jeronim pokušao ispraviti evanđelje protiv svih objektivnih i sveopćih pravila. Iako za njih kaže slikovito da je za magarca uzalud udarati liru, ipak se odlučio odgovoriti im: » Ja nisam tako glup, ni tako grubi prostak, pa da sam mislio ili da što od riječi Gospodnjih treba popraviti, ili da je ondje što pisano bez Božjega nadahnuća: nego latinskih knjiga pogreške, kojima su dokaz razlike svih primjeraka, htio sam

\footnotetext{
${ }^{2}$ Usp. Pismo Inocenciju svećeniku o sedam puta udaranoj, I, 1-2: Patrologia Latina (dalje: PL) 22, 325327. Osnovni izvor za ovaj rad poslužilo nam je djelo: JERONIM, Izabrane poslanice, Split, 1990. U radu smo se koristili sljedećim izvorima: MIGNE, Patrologia Latina, volumen 23; Patrologia, volumen III. Dal Concilio di Nicea (325) al Concilio di Calcedonia (451). I Padri latini a cura di A. di BERARDINO con presentazione di J. QUASTEN, Assisi, 1992.; Kao poticaj ovom radu bili su izvođeni seminari o sv. Jeronimu na Katoličkom bogoslovnom fakultetu.

${ }^{3}$ Rufinu, III, 1-5: PL 22, 332-335.

${ }^{4}$ Usp. Pismo Eustohiji, XXII, 30-31: PL 22, 416-417.
} 
ispraviti po grčkom izvoru, iz koga one bijahu prevedene, kako i sami priznaju. $\ll^{5}$ On kritizira njihovo neznanje i na taj način u njima stječe neprijatelje. Jeronim je iskren, energičan i otvoren u dijalogu, ali u tome ne bira stil i osebujnost slikovitoga izražavanja s nakanom prikazati u lošem svjetlu svoje sugovornike. Oni su dvonogi magarci, kojima treba trubiti u uši, a ne svirati im citru. Oni samo nagađaju, a ne znaju tumačiti Božju riječ. Marceli se opravdava da se prema protivnicima nije služio oštrim riječima: »Jedno samo rekoh da djevice moraju češće biti kod ženskih nego li kod muških glava: pa, jadan ja, cijelom se Rimu zamjerih, svak me prstom pokazuje! 'Oni koji na me mrze bez uzroka, umnožiše se više nego je kose na glavi mojoj; i postadoh im za priču. $\ll^{6}$

\subsection{Pred tajnom Božje RiječI}

Zaljubljenik je u Sveto pismo pa kao takav Jeronim piše svećeniku Paulinu iz Nole o toj zaljubljenosti, a piše i o onima koji se prema Svetom pismu ponašaju neozbiljno. Uspoređuje s drugim pozivima, npr. gramatičar se bavi gramatikom, govornik govorništvom, zidar zidanjem, umjetnik umjetnošću, a znanje o Svetom pismu na sve strane svatko sebi prisvaja. ${ }^{7}$ Piše: $\gg$ Baka blebetuša, starac koji je izvjetrio, sofist govorljivi, svi cijene da ono znanje imaju: svi raskidaju sveto Pismo, svi su učitelji prije nego će biti učenici. $\ll^{8}$ Poučavati druge o nečemu što ne poznaješ, to je neozbiljna ili šarlatanova igra. Kolika je ozbiljnost pristupa tekstovima Svetoga pisma, vidi se $\mathrm{u}$ tome što Jeronim Paulinu nabraja gotovo sve biblijske knjige, tvrdi da svaka od njih diše nebeskim tajnama, a da netko tko je neozbiljan i neuk ne može razumjeti i tumačiti Riječ Božju. Išao je toliko široko, gotovo energično i temperamentno pisati, da je napisao da ga je zanijela ljubav prema Svetom pismu pa je prešao s pisanjem izvan okvira poslanice. Ponizan je pred stvarnošću Svetoga pisma: »Nisam toliko bezobrazan ni tupoglav pa da se ističem da znam one knjige i da berem rod $s$ onog drveta kojemu su žile utvrđene na nebu; ali ispovijedam da to želim. $\ll^{9} \mathrm{Nalazi}$ se pred Svetim pismom kao Misterijem, gotovo jednako kao pred samim Bogom kojega ne može spoznati, ali kojoj spoznaji želi težiti. Jeronim je pretrpio mnogo prigovora zbog prevođenja tekstova.

Jednom je u Jeruzalemu preveo poslanicu s grčkog na latinski jezik, jer ga je zamolio jedan njegov subrat monah koji nije poznavao grčki jezik, što je Jeronim i učinio. Učinio je to pod uvjetom da monah tu poslanicu ne daje nikome na uvid jer ju je preveo

\footnotetext{
${ }^{5}$ Pismo Marceli, XXVII, 1: PL 22, 431.

${ }^{6}$ Isto, XXVII, 2: PL 22, 432.

${ }^{7}$ Usp. Pismo Paulinu svećeniku, LIII, 6: PL 22, 544.

${ }^{8}$ Isto, LIII, 7: PL 22, 544.

${ }^{9}$ Isto, LIII, 9: PL 22, 549.
} 
samo radi zajednice i samog monaha, no, ovaj je uskoro proširio po čitavom Jeruzalemu Jeronimov prijevod. Nakon toga uslijedile su kritike na račun Jeronimovog prijevoda. U ovom kontekstu Jeronim donosi prilično oštar sud i tvrdnju: »Ono što državni zakoni, što neprijatelji poštuju, što je usred rata i pod oružjem nepovredivo, to nam je među monasima i Kristovim svećenicima ostalo nezaštićeno. $\ll{ }^{10}$ Toliko o čuvanju povjerene tajne među crkvenim osobama, kojima povjerenje nije sveto. Gledaju samo što je njima korisno i probitačno, a u stvari radi se o zlodjelu i zločinu.

Kao ni jedan crkveni otac Jeronim se bavio prevoditeljskim radom, a zaključiti se dade da je taj posao činio ne samo što je bio za to sposoban nego više iz razloga što je želio pomoći kršćanima da oni bolje razumiju tekst, bilo svetopisamski bilo unutarcrkveni. A upravo je prevoditeljski rad osebujan i zahtjevan, a neprestano je pod prizmom kritike. Svjesno je napisao, imajući u vidu svoje druge prijevode i prijevode poganskih prevoditelja, da nitko ne može prevesti draž jezika koji je napisan u izvornom, domaćem obliku. Tako Jeronim kao kršćanski prevoditelj ide uz bok najboljim prevoditeljima ondašnjega grčko-rimskoga miljea.

\subsection{Ponizan ŽIVot PRED Bogom}

Poslanica biskupu Heliodoru pisana je 396. godine u trenutku kada je kao vrlo mlad umro monah Nepocijan, biskupov nećak, i u njoj Jeronim otkriva svoju dušu i srce kroz prijateljske osjećaje prema pokojniku. On u trenutku smrti žali mladi život, ispunjen svetošću, ali zaključuje kako je ipak Nepocijan smrću izbjegao zlima svijeta svoga vremena: veliki događaji koji su kobno utjecali na rimsko doba: raspadanje carstva, prebrzi nestanak careva, pogibija uglednih osoba, propadanje kulturnoga nasljeđa, doba kulturnih i društvenih događanja, a uzrok tomu su, smatra sv. Jeronim, ponajviše grijesi ljudi, i to crkvenih službenika i vjernika laika. Ljudski grijesi uzrok su propadanja i, unatoč zlu koje se nadvilo nad čovjekovu sudbinu, Jeronim s pozitivnim stavom poziva na obraćenje riječima: $\gg$ Ako se želimo podignuti, padnimo pred Boga. Ah, velike sramote! $\ll{ }^{11} \mathrm{Uz}$ dušu i srce, Jeronim otkriva i svoje razmišljanje o smrti, kako ona nije umiranje, nego seljenje, nije ostavljanje prijatelja, nego zamjena za nove prijatelje koji su kod Boga.

\section{Razvijati suradnju sa svećenicima i monasima}

Crkveni službenici, prije svega svećenici i đakoni, nisu mogli proći nedodirnuti u Jeronimovu pisanju. Pronašli smo Jeronima kao onoga koji je pristupao svećeničkom pozivu s mnogo poštovanja, zbog kojega se tom pozivu i opirao. Svećeništvo

\footnotetext{
${ }^{10}$ Pismo Pamahiju o najboljem prevođenju, LVII, 3: PL 22, 569.

${ }^{11}$ Pismo Heliodoru, LX, 17: PL 22, 601.
} 
je zahtjevno i velika obveza, ono je prije svega služenje zajednici i u zajednici, a od onoga tko je to prihvatio tražio je nesebično predanje i služenje, odbacujući svaki oblik pohlepe za materijalnim dobrima i za čašću, zahtijevao je primjerno vladanje i predanost Kristu. U pismima se nalazi sve što je vezano uz klerika, i ne samo klerika nego i monaha, od pohvale do kritike, od radosti do očaja, od ohrabrenja do poticanja na samospoznaju vlastite grješnosti, od grješnosti do obraćenja. Pisma otkrivaju i kakav je Jeronim bio u tom smislu. ${ }^{12}$

\subsection{Prijateljstvo kao oči U glavi}

Rufin mu je prijatelj, upoznali su se u Akvileji i potom zajedno krenuli na istok, $\mathrm{u}$ Betlehem, pa se na kraju razdvojili. Rufin je zastao u egipatskim pustinjama među monasima, koje Jeronim naziva nebeskom obitelji na zemlji, i iz Betlehema mu piše da bi volio biti prenesen u egipatske pustinje i zagrliti ga, ali ne može $\gg$ jer mi česte bolesti sasvim oslabiše tijelo, nemoćno i kad je zdravo, mjesto sebe ovu ti poslani$\mathrm{cu}$ šaljem na susret da te uzicom ljubavi svezana $\mathrm{k}$ meni dovede. ${ }^{13} \mathrm{Za}$ sebe kaže da je često tjelesno slab i uvijek boležljiv. Inocencija naziva jednim svojim okom kojega je nenadano izgubio, a Evagrije mu je drugo oko s kojim može još gledati. $S$ Rufinom razmjenjuje iskustvo monaha, posebno monaško iskustvo zajedničkoga im prijatelja Bonosa, koji boravi kao monah u pustinji. Kao i često puta, Jeronim se i sada više oduševljava tuđim uspjesima i krjepostima nego svojim, što se vidi iz osobnoga obraćanja Bogu:

$\gg$ Hvala tebi, Gospodine Isuse, što imam onoga koji će ti se u dan tvoj za mene moliti.Jer ti (... ) ti, velim, znaš kako smo ja i on zajedno od malena do snažne dobi uzrasli, kako su nas iste doilje na krilo uzimale, isti odgojitelji grlili i milovali, pa nakon što dovršismo nauke u Rimu ( ... kako sam ja prvi zaželio tebi služiti. (... ) Neka on uživa vijenac za svoje kreposti i za svakidašnje mučeništvo obučen u stolu neka ide za Jaganjcem. Jer su mnogi stanovi u Oca i zvijezda se od zvijezde razlikuje u svjetlosti, a meni daj da glavom dosegnem do pete svetaca tvojih; i jer željah što on izvrši, meni prosti što nisam mogao ispuniti, a njemu daj zasluženu plaću. ${ }^{14}$

Na drugom mjestu Jeronim će reći da je monah Bonos zaslužio krunu, a da on leži u grobu svojih opačina, zavezan uzicom grijeha i čeka da mu Gospodin kaže: Jeronime, izadi van! ${ }^{15}$

${ }^{12}$ Usp. A. MIŠIĆ, Elementi svećeničke duhovnosti u pismima Sv. Jeronima, u: Obnovljeni život 45(1990.)4, 219-231.

${ }^{13}$ Pismo Rufinu, III, 1: PL 22, 332.

${ }^{14}$ Isto, III, 5: PL 22, 334.

${ }^{15}$ Usp. Pismo Hromaciju, Jovinu i Euzebiju, VII, 16: PL 22, 338-340. 


\section{2. ČUVANJE Mira U ZaJEDNICI}

Iz pisma upućenoga đakonu Julijanu u Akvileju možemo pobliže saznati koji su problemi mučili Jeronima. On se đakonu jednostavno ispričava, moli njegovo oproštenje. Naime đakon Julijan, koji se brine o njegovoj sestri, a koju je on obratio i priveo u monahinje, optužuje Jeronima da mu se ne javlja, ne piše mu. Nije istina da mu se Jeronim nije javljao i pisao, nego je istina da one osobe koje su prenosile napisane listove od Jeronima nisu ih donijele na odredište. Listonoše su zakazale. ${ }^{16}$ Jeronim se žali u iskrenosti svojega srca da ga muče tjelesne bolesti, a k tomu još više duhovni jadi. Gotovo se susreo sa smrću i tada je i na sebe zaboravio. On se đakonu povjerava, razotkriva sebe i svoju muku i jad. Zbog toga njegova stanja i drugih opačina subrat Heliodor, kojega je zvao svetim, od njega je otišao jer nije mogao trpjeti Jeronimove jade. Iako mu je stalo do iznošenja istine na van, a ona je u ovom slučaju da je on ipak pisao pismo đakonu, a da su drugi zakazali, tvrdi da je bolje tražiti mir nego izazivati borbu. U tom slučaju prednost daje očuvanju mira s klericima pred dokazivanjem istine. Ono što piše o sebi monahinji Eustohiji dobro se uklapa u taj kontekst: »Što je god putene vlage u meni bilo, usahnulo je, i iznemogoše od posta koljena moja, te zaboravih jesti kruh svoj. Od jecanja i uzdisanja moga prionu kost moja za meso moje. $\ll{ }^{17}$

\subsection{ZAVIČAJ U SRCU}

S nostalgijom se Jeronim zanima za svoj zavičaj, ima li ga još na životu, pita đakona. Trima monasima piše da je u njegovu zavičaju trbuh Bog i živi se bez ikakve brige za budućnost. Onaj koji je bogatiji taj je svetiji. Put ga je odveo daleko na istok, ali svoga zavičaja i porijekla ne zaboravlja i tomu pristupa s realnošću. ${ }^{18}$

Trojicu monaha, Kromacija, Jovina i Euzebija, ne štedi od kritike. Drži ih doista svojim prijateljima koji su nerazdvojni iz vremena boravaka u Akvileji i za koje kaže da su tri u jednome, a jedan u trima. Oni su se njemu javili, ali vrlo kratkim pismom, što ga je rastužilo. Naziva ih lijencima jer su malo napisali, kao da nemaju vremena i kao da nemaju papira. Jeronim se i ovdje pita je li možda zaslužio da se tako ponašaju prema njemu koji s mnogo ljubavi očekuje potvrdu svoje ljubavi prema monaškom životu is mnogo iskrene čežnje očekuje čuti ponešto o životu u svome zavičaju.

Gotovo je prošlo vrijeme iščekivanja pisma od nekoga; nekada je to bio događaj koji je unosio promjene u život, iščekivanje je bilo praćeno različitim emocijama,

\footnotetext{
${ }^{16}$ Usp. Pismo Julijanu, dakonu u Akvileji, VI, 1: PL 22, 337-338.

${ }^{17}$ Usp. Pismo Eustohiji, XXII, 17: PL 22, 404-405.

${ }^{18}$ Usp. Pismo Hromaciju, Jovinu i Euzebiju, VII, 3: PL 22, 338-340.
} 
koji put je pisana riječ bila život i budila je život. S pismom je stizala i osoba, čežnja za susretom s tom osobom značila je mnogo više od pukoga čina pisanja. Kao da je Jeronimov stav i načelo u pisanju pisama utemeljeno u onome što kaže sv. Petar: $\gg$ Prije svega, imajte žarku ljubav jedni prema drugima; jer, ljubav pokriva mnoštvo grijeha $\ll(1 \mathrm{Pt} 4,11)$.

Čini se da se Jeronim koristi svakom prilikom kako bi iznio svoje mišljenje ili stav prema muškim osobama. Ponajprije se njegovo razmišljanje odnosi na svećenike ili klerike, a onda i na monahe, koji se nalaze u istoj službi kao i on. Naznačivši svoje promišljanje o ženama, usmjerava se prema muškarcima, monasima, $s$ iskrenom namjerom postići barem neizravno poboljšanje svećeničkoga života, jer poneki put znao je reći da ga stid obuhvaća kad mora pisati o životu i ponašanju crkvenih osoba. Evo donosimo nešto od rečenoga, a upućeno ženi Eustohiji:

$\gg$ Ali nek se ne bi činilo da govorim samo o ženama, kloni se također ljudi koje vidiš lancem opasane štono im je, unatoč apostolovoj zabrani, dugačka kosa, jarčja brada, crna kabanica i gole noge u kojima ne osjećaju zime. To su sve sotonski znakovi. (...) Oni, pošto se uvuku u vlasteoske kuće i prevare ženice opterećene grijesima, koje uvijek uče a nikad ne mogu doći poznanju istine, pretvaraju se da su žalosni, i duge tobožnje postove produžuju, potajno obnoć jedući. Ostalo, stid me je kazati, da se ne pomisli da više napadam nego opominjem. Ima drugih - govorim o ljudima svoga reda - koji stoga traže svećenički ili đakonski čin da slobodnije mogu vidjeti žene. Njima je svakolika briga za odjeću, da li dobro mirišu, da li im se noge amo tamo, poput mijeha, u širokim postolima ne giblju. Kosa im je gvožđem uskovrčena: od prstenja im sjaju ruke; i da im se tabani ne poprskaju od mokra puta, tek prstima staju na zemlju. Kad takove vidiš, drži ih za mladoženje više nego za ljude crkvene. Neki uložiše sav trud i život da saznaju imena gospođa, njihov dom i vladanje... $\ll{ }^{19}$

Jeronim živi u vrijeme s kraja četvrtoga na peto stoljeće, u vrijeme kada je Crkva sa svojim službenicima uživala slobodu nastupanja i djelovanja, štoviše, uživala je i poneke povlastice druge naravi o kojima nije mogla ni sanjati u vrijeme progona. Biti kršćanin, biti crkveni službenik, bila je zasigurno povlastica koja je vodila u suprotnom smjeru. Svakako da Jeronimu, monahu i isposniku, pustinjaku i asketi, nije odgovaralo slobodnije ponašanje, posebno je izražavao svoje nezadovoljstvo kada su u pitanju monasi i njegovi prijatelji poznanici. Koliko god mi isticali samotnički život i isključenost iz svijeta, Jeronim se ipak predstavlja kao dobar poznavatelj dobrih i loših primjera u vlastitoj i široj okolini. Dovoljno je uzeti u razmatranje

${ }^{19}$ Pismo Eustohiji, XXII, 28: PL 22, 413-414. 
spomenute pasuse pa da na najbolji način ocrtaju osobnost i Jeronimov stav prema društvenoj i crkvenoj stvarnosti. To je stoga što je on strog i prema sebi, jer kaže: »Prije puno godina kad se, za kraljevstvo nebesko, odrekoh kuće, roditelja, sestre, rodbine, i što je od toga mučnije, svakidašnje gospodske hrane, pa pođoh u Jeruzalem da vojujem, ne mogah nipošto biti bez knjižnice, koju najvećom marljivošću i trudom bijah u Rimu namakao. ${ }^{20}$ Knjiga iz njegove knjižnice bijaše mu rješenje njegovih monaških i ljudskih problema.

\subsection{RASPRAVE SA SVEĆENICIMA}

Drži se da je Domnion bio svećenik u Rimu komu Jeronim piše o nekom obraćenom odvjetniku na monaštvo. Taj obraćenik klevetao je Jeronima, podcjenjivao njegove intelektualne i duhovne sposobnosti. U poduljem izlaganju upoznaje svećenika Domniona o zloj strani klevetanja, ali ne štedi u napadima spomenutoga monaha, ali istovremeno ga poziva da se obojica ogledaju na književnom polju i da čitatelj donese presudu. Poručuje mu, među ostalim, neka se hvata posla, ne lakrdijaštva i blebetanja, neka pisaljkom gradi brazde. Samo kad bih htio, veli Jeronim, mogao bih mu vratiti rječitošću, tako ga jako iščešljati da se osramoti na svoju žalost. Ali volim biti učenik Isusov. Doista dobra pouka za mlađega svećenika, kojega čeka sličan svijet. ${ }^{21}$ Glavna se rasprava vodila između Jeronima i toga obraćenoga monaha o tumačenju Svetoga pisma. Jeronimu je spočitavao stručnost u tumačenju, na što je Jeronim molio da mu pošalje svoju knjigu koju je napisao pa da ju on ispravi pa će vidjeti tko o Svetom pismu čavrlja. Isto tako monah je tvrdio da Jeronim osuđuje ženidbu i udaju. Stoga zaključuje: $\gg$ A sad, ako ne će pisati, već cijeni da mu treba samo psovati, kad nas ovoliko kopno, more i narodi dijele, bar neka čuje odjek moje vike: Ne osuđujem udadbe, ne osuđujem ženidbe. I da još sigurniji bude o mome mišljenju, hoću da se žene svi koji, možda poradi straha noćnoga, ne mogu spavati sami. $\ll^{22}$ Izazvan protivnikom, Jeronim iznosi svoj stav i naučavanje o Svetom pismu, monaštvu, svećeništvu i ženidbi. A o svemu tome mu je prigovarano.

\subsection{GOVOR O SVEĆENIŠTVU}

Crkveni čovjek, ovdje misli na svećenika, ne može živjeti životom svjetovnih ljudi. On mora imati više prostora za siromašne, više prostora za Isusa Krista, više prostora za Sveto pismo i svete knjige, više prostora u životu za samoću i duhovnu čistoću, više prostora za skromnije odijevanje, a manje za bogataše, manje prostora za

\footnotetext{
${ }^{20}$ Isto, XXII, 30: PL 22, 416.

${ }^{21}$ Usp. Pismo Domnionu, L, 4: PL 22, 514.

${ }^{22}$ Isto, L, 5: PL 22, 515.
} 
trgovine, manje prostora za trgove i suvišne razgovore, a najmanje prostora crkveni čovjek, odnosno klerik (što znači baština Božja!) treba imati za žene. U ženama Jeronim vidi veliku zaprjeku za krjepostan i čist život koji treba resiti svećenički život. Monah nikada ne smije govoriti o ljepoti žena, a niti govoriti u jednoj kući što se događa u drugoj. $S$ druge strane golemo se poštovanje prema ženama pronalazi u Jeronimovim spisima, posebno ondje gdje vlada sveta ljubav između muškarca i žene, a sveta ljubav ne poznaje čestih međusobnih darivanja, čestih korištenja maramica zbog plakanja, sveta ljubav ne poznaje česte posjete udovicama, sveta ljubav ne poznaje umiljata i ljubazna pisanja, sveta ljubav isključuje često motrenje ženskoga lica. Jednostavno, trebaju se slagati usta, duh i ruke kršćanskoga svećenika.

Jeronim posebno ističe ulogu svećenika kada su u pitanju materijalna dobra Crkve. Ako bi svećenik zakinuo Crkvu, povrijedio bi svetinju. Prisvojiti sebi nešto što pripada drugomu, posebno ljudima u potrebi, ravno je nemilosrđu svakoga razbojnika. ${ }^{23}$

\subsection{Pod Cijenu prijateljstVa}

Jeronimov rad često povezujemo s radom na Bibliji. Tumačenjem biblijskih tekstova i njihovih prijevoda došao je u nesporazum sa sv. Augustinom. Neuspjela su dopisivanja između te dvojice velikana svojega vremena. S velikim poštovanjem Augustin je pristupao misli i djelu što su izlazili iz Jeronimova uma i pera, a Jeronim je s ljubavlju pristupao biskupskoj služi u osobi Augustina. Ali nesporazumi su nastali kada su si treće osobe pokušale na prevarantski način prisvojiti pisana dostignuća te dvojice. Njih su dvojica razmjenjivala pisma, a zapravo nisu imali objektivno saznanje o posrednicima, prenositeljima njihovih pisama. Drugi su, đakoni, neodgovorno postupili jer su širom razdijelili ono što je Augustin pisao Jeronimu, a da ni jedan ni drugi za to nisu znali. Širile su se laži da je Augustin pisao pismo u Rim biskupu žaleći se na Jeronimov rad na biblijskim tekstovima, a budući da su te glasine stizale do Jeronima, Jeronim je tražio pojašnjenje od Augustina. Često se Augustin javljao Jeronimu, no ovaj mu je odgovorio:
»Dakle, kako sam ti već prije pisao, ili mi opremi istu poslanicu svojom rukom potpisanu, ili se prođi dosađivati starcu sakrivenu u ćeliji. Ako li pak hoćeš ili da se vježbaš, ili da svoje znanje na vidik iznosiš, traži ljude mlade, rječite i odlične, koji će moći i smjeti s tobom se ogledati, i što se tiče razlaganja svetog Pisma, s biskupom natezati se u jednakom radu (... ). Traži, velim, druge ljude, a ne sam nanovo da se bijem iznemoglim tijelom. $\ll^{24}$

\footnotetext{
${ }^{23}$ Usp. Pismo Nepocijanu, LII, 15: PL 22, 538-539.

${ }^{24}$ Pismo Augustinu, CV, 3: PL 22, 831.
} 
Jeronim je umoran od beskorisnoga dopisivanja pa zaključuje: $\gg$ Zbogom, premili moj prijatelju, po godinama sine, po dostojanstvu oče; i pazi na ovo što te molim: što mi god pišeš, gledaj da meni najprije dođe u ruke. $\ll^{25}$

\subsection{RAZMIŠLJANJE O MONAŠKOM ŽIVOTU}

Monaški život ideal je kršćanskoga života i zato s mnogo ljubavi Jeronim potiče Rustika da ustraje u monaškom životu. Ništa nije vrijednije od povlačenja u samoću, od napuštanja gradske vreve, ni ljubav prema majci nije kao ljubav prema samotnom životu. Jeronimu je grad tamnica, a samoća raj. ${ }^{26} \mathrm{~A}$ ako bi Rustik htio postati svećenik, odnosno crkveni službenik, Jeronim će to ipak prihvatiti s oduševljenjem. Veli mu:

$\gg$ Ako te mori želja za crkvenim redom, uči ono što ćeš biti kadar poučavati, i sebe, žrtvu razumnu, prinosi Isusu Kristu, i ne budi vojnik prije nego novak, ni učitelj prije nego učenik. Ne pristoji se mojoj malenkosti, i nisam do te mjere dorastao, da bih sudio crkvene ljude, ni da bih kakvo zlo kazivao na crkvene službenike. $\ll{ }^{27}$

Često se događa da Jeronim baš kritizira monahe zbog načina njihova života: ugled u društvu, posjedovanje imanja, pohlepa za novcem, česti boravak u društvu žena, neispunjavanje reda i propisa, čine što hoće, ne boje se nikoga, drže svakoga za manjeg od njih, češće su u gradovima, vrevi i buci nego u kući, teže za višim dobitkom nego svjetovni ljudi... Svjedoči: »Vidio sam svojim očima neke pošto se odrekoše svijeta - naravno odjećom i usmenom izjavom, a ne djelima - ni u čemu ne promijeniše prijašnje svoje življenje. $\ll^{28}$ To je izravni povod kritikama koje stižu na njegov račun i on je toga svjestan kada kaže Rustiku da će ga svi zamrziti i da će ga obasipati psovkama baš zato što kritizira duhovne mane monaha kojima se ovaj kani priključiti. Jeronim priznaje svoju grješnost od prije i od sada, grješan je kao i drugi, ali pravi razliku u tome što u sebi vidi čovjeka kojemu nisu mili vlastiti grijesi, on ih mrzi, dok kod drugih ističe tu slabost da oni vole grijeh. Za njih može reći da manu liječe manom, a grijeh grijehom. Upoznaje mladoga monaha da u svakoj crkvi nema nego jedan biskup, jedan arhisvećenik, jedan arhiđakon, i sav crkveni život počiva na tomu.

Pozitivno se izjašnjava o ljudima koji imaju svećenički red: »Ljudi svećeničkog reda sveti su, i sviju njih pohvalno je življenje. Tako vladaj se i živi u manastiru da

\footnotetext{
${ }^{25}$ Isto, CV, 5: PL 22, 837.

${ }^{26}$ Usp. Pismo monahu Rustiku, CXXV, 8: PL 22, 1076-1077.

${ }^{27}$ Isto, CXXV, 8: PL 22, 1077.

${ }^{28}$ Isto, CXXV, 16: PL 22, 1081-1082.
} 
budeš vrijedan postati čovjek crkveni. $\ll^{29}$ Jeronim se ponaša gotovo kao duhovni i životni savjetnik mladom čovjeku, priprema ga za budući život.

\subsection{LUTAJUĆI KLERICI}

Jeronim poziva Sabinijana, đakona, na pokoru. Pred sobom ima lošu životnu situaciju lutajućih klerika. Posebno kritizira lutajuće klerike, tvrdoglavi su i nepokorni, poziva ih da prestanu robovati ugledu, putenosti i nemoralu. Oni su za Jeronima nerazumne životinje, tupani, osiljeni koji ne misle nikada umrijeti. Ne drže ništa do prorokovih riječi, odnosno do svetopisamskih. Oštre su Jeronimove riječi, diraju ne samo pojedinca unutar Crkve ili monaške zajednice nego su one prozivanje svih crkvenih osoba sličnoga profila življenja. Koliko god se činilo da Jeronim kritizira i upozorava pojedinca, isto se toliko može činiti da je to istovremeno poziv čitavoj Crkvi. Jeronim je svevremenski.

Jeronim je od Sabinijana primio pismo i čitao ga, kako kaže, prestrašenom dušom. Što je to Jeronima toliko prestrašilo? Teško je znati što je to Sabinijan pisao i s kojom namjerom, možda je očekivao opravdanje ili razumijevanje za počinjena loša djela. Baš suprotno, Jeronim kaže da je cijelu sliku njegovih djela nacrtao u pismu kao na daščici, sve mu je događaje stavio pred oči. I doista, ne štedi ga Jeronim, navodi mu sva njegova neuredna i nemoralna zastranjenja, uspoređuje ga s biblijskim likovima, kraljevima i Izraelcima, koji su obeščastili hram i Šator Božji. Podsjeća ga:

$\gg$ Pao si stoga preda mnom na koljena, i molio si za pola mjerice krvi: ti si se jadan kakav jesi, ne mareći za sud Božji, bojao mene kao osvetnika! Ispovijedam da sam ti oprostio. A što bih ti, ja kršćanin, mogao drugo učiniti? Savjetovah te da činiš pokoru, da se u kostrijeti i pepelu valjaš, da ideš u pustinju, da živiš u manastiru, da neprestanim suzama prosiš Božje milosrđe. Ali ti, potporo dobre nade, zmijinjim žalcima razdražen, postade mi luk iskrivljen te puštaš strijele svojih psovki. Ja ti postadoh neprijatelj, govoreći istinu. $\ll^{30}$

Jeronimovo prijateljstvo sa svima kojima je pisao moglo bi se s lakoćom povezati s prijateljstvom s Bogom, o čemu govori psalmist koji je prijatelj svima koji se Boga boje i koji čuvaju Božje naredbe (usp. Ps 119, 63).

Iz pisma izvire bratsko suosjećanje s grješnikom. Jeronim je prije svega kršćanin, ali i grješnik, grješnik koji čini pokoru i za svoje se grijehe kaje, on je iskrene duše, ne uzmiče ni pred grijehom ni pred pokorom i kajanjem, on pada i diže se iz svoje grješne prošlosti.

\footnotetext{
${ }^{29}$ Isto, CXXV, 17: PL 22, 1082.

${ }^{30}$ Pismo Sabinijanu, CXLVII, 8: PL 22, 1201.
} 


\section{Promicati dostojanstvo i ulogu žene}

Već smo spomenuli da su žene dobar motiv i snažan povod mnogim pismima koje je Jeronim pisao. Nekoliko desetina pisama bilo je upućeno ženama: udovicama, monahinjama, djevojkama, majkama, suprugama, bogatim i uglednim rimskim građankama, prijateljicama, pojedinačno i u zajednici. Kakva je ljudska psiha u susretu sa ženskim svijetom i kako izgleda ljudska slabost na toj relaciji, može se dobrim dijelom otkriti u Jeronimovim pismima.

\subsection{Priče MEĐU DJEVICAMA}

Jeronim boravi u pustinji na istoku i čini se da ima vremena za razmišljanje i pisanje. Bori se kratko pisati, svjestan da dužina sadržaja otežava komunikaciju s drugima, ali često puta ne uspijeva. Svjestan toga, piše kraće pismo monahinjama u Emonu. Kao monah mnogo komunicira s vanjskim svijetom pismima. Razlozi tomu mogu se tražiti u njegovoj glasovitosti među monasima, ali i u njihovoj potrebi za intelektualnim i duhovnim poučavanjem. I u slučaju emonskih djevica ističe istu poteškoću kao i s klericima. Toliko puta je prema njima iskazao svoju ljubav, a one mu se ni jednim naslovom nisu odužile. Piše im: $\gg$ A vi - molim oprostite meni tužnu; oprostite što ću uvrijeđen reći, što ću reći roneći suze - vi ni sâmom jednom titlom ne podariste onoga koji je prema vama svoju dužnost toliko puta izvršio! « 31 One mu nisu odgovarale na njegovo pisanje iz razloga što su čule o njegovu lošem ponašanju. Jeronim pretpostavlja da je to razlog i stoga ih podsjeća na nekoliko Isusovih riječi koje kažu da je Isus došao radi grješnika, a ne pravednika. Priznaje pred njima da je grješnik i da je tmina: $\gg$ Znam da nema zajednice svjetlosti $s$ tminom i da grešniku nema udruživanja sa službenicama Božjim. $\ll^{32}$ Sagledavajući šire, saznaje se da su emonske djevice priče o Jeronimu čule preko drugih monaha, posebno jednoga monaha Antonija. Jeronim to zna pa piše Antoniju deset pisama, a ovaj se ne javlja, vjerojatno svjestan što je okolo pripovijedao. Među ostalim navodi mu primjer Gospodina koji je razgovarao sa slugama, a on kao brat s bratom ne će razgovarati. I nastavlja: »Ali vjeruj mi, da me nije stid pisati, kao čovjek uvrijeđen tako bih te izružio... « ${ }^{33}$ Živopisno i trajno aktualno prikazani su međumonaški i međusvećenički odnosi kada je u pitanju netko drugi. Jeronim je ponizan i taj put, poziva monaha da u sebi probudi bratsku ljubav i da mu se javi, ne ruži ga. Poziv je to na pomirenje uz prethodno traženje oproštenja.

\footnotetext{
${ }^{31}$ Pismo emonskim djevicama, XI: PL 22, 345.

${ }^{32}$ Isto.

${ }^{33}$ Pismo Antoniju, monahu Emone, XII: PL 22, 346.
} 


\subsection{Govor BEZ LASKANJA}

Kao velik poznavatelj i ljubitelj Svetoga pisma Jeronim se koristi svakom prilikom da u svoju misao umetne pokoji biblijski starozavjetni ili novozavjetni citat. Mogu se pronaći brojna mjesta iz Biblije koja vješto povezuje s problemom ili temom o kojoj piše. U tom duhu piše malo poduže pismo Eustohiji, kćeri njegove prijateljice Paule. Ona se odlučila ući u monaški red i on joj pruža značajnu podršku stavljajući joj pred oči milosnu prednost monaškoga života spram onoga bračnoga. Svijet je Sodoma, škorpioni, zmije, svijet iz kojega je Eustohija izišla i ušla u monaški život i bez obzira na to što ju podržava i raduje se, ne štedi je: »Jer u ovoj knjižici ne će biti nikakva ulagivanja, budući da je laskavac umiljati neprijatelj. Ne će biti nikakva retorskog nakita kojim bih te i među anđele stavio; te razloživši blaženstvo djevičanstva, metnuo ti svijet pod noge. $\ll^{34}$

Takav stav poučava kako postupati prema svima onima koji se odlučuju slijediti Krista svećeničkim ili redovničkim životom. Laskanje, ulagivanje, umiljavanje kandidatu, obećavati mu da će se pod njegove noge podložiti čitav svijet, Jeronimu nije prihvatljiv način. Nasuprot tomu on gaji žarku ljubav prema Eustohiji, želi je poučiti kako se boriti protiv trnja i bodljika ovoga života, protiv neprijatelja koji okružuje čitav svijet. Eustohija je kao žena za Jeronima puna zlata i valja je čuvati od razbojnika. Ako Eustohija ne shvati ozbiljnost zahtjeva monaškoga života, vrijedi ono što joj kaže Jeronim: »Bolje je bilo poći za čovjeka. ${ }^{35}$ Svoje iskustvo monaškoga života Jeronim predstavlja Eustohiji. U pustinji je osjetio Božju blizinu naspram ljudske bijede i jada:

>I samome meni, kad bijah u pustinji, u onoj velikoj samoći, izgorjeloj od žestine sunčanih zraka, koja je monaško strašno prebivalište, o koliko se puta činjaše da se nalazim na rimskim zabavama! Sjeđah nasamo jer bijah pun jada. ( ... Svaki u Boga dan prolivah suze, svaki bogovetni dan uzdisah, i ako bi me katkad protivu moje volje san obrvao, o golu zemlju razbijah kosti svoje, koje jedva prijanjahu jedna za drugu. (...) Pa baš ja koji poradi straha od pakla, sam sebe bijah osudio na onakovu tamnicu; ja kome su jedino društvo bile škorpije i zvjerad, često se nalažah između djevojaka što igrahu kolo. (... I tako ostavši bez svake pomoći, padah pred noge Isusove, oblivah ih suzama, vlasima ih svojim otirah, i gladujući za više nedjeljâ danâ pokoravah tijelo koje mi se opiraše. Nije mene stid ispovjediti jad i nesreću svoju, nego plačem da nisam ono što sam bio. Sjećam se kako mnogo puta vapijah, za danom obnoć nastavljajući,

\footnotetext{
${ }^{34}$ Pismo Eustohiji, XXII, 2: PL 22, 395.

${ }^{35}$ Isto, XXII, 6: PL 22, 397.
} 
i ne prestajah lupajući se u prsi dok se, na glas Gospodinov, ne bi vratila tišina. $\ll^{36}$

Dok opisuje kakve se sve žene pojavljuju u društvu, među kršćanima, među monahinjama, izražava svoj stid zbog toga. Dobro poznaje njihovo ponašanje, u detalje opisuje njihovo odijevanje, riječi, namjere, posljedice. A kada tako vjerno oslikava ženski rod, onda njega drugi nazivaju sumnjivcem, kako sam za sebe napisa. Inače, čini se, kada su žene u pitanju, Jeronimov odnos prema njima od samih početaka monaškoga življenja stavlja se pod prizmu sumnje ili barem znatiželjnoga propitkivanja.

Jeronim uključuje u svoje pisanje i odnos svećenika prema ženama. U pismu Eustohiji, u kojem je upućuje na ispravan monaški život, među ostalim piše:

»Čaki ljudi crkveni koji valjalo bi da budu učitelji nauke i straha Božjega, laskaju poglavitim gospođama, i pružajući ruku kako bi se moglo misliti da blagoslivlju; ako ti je drago znati, primaju plaću za učinjeni poklon. One međutim kad spaze da svećenici trebaju njihove zaštite, osile se. I jel iskusiše muževlju vlast, vole slobodu udovištva; nazivlju se čiste i duhovnice, a po bogato postavljenoj večeri, u snu vide apostole. $\ll^{37}$

Nakon što je izložio jedan dio teme o djevicama zaručnicama koje su krenule za Kristom, zanimljivim načinom i tonom Jeronim se obraća Eustohiji: »Stoga, moja Eustohija, kćeri, gospodarice, drugarice u službi, sestro - prvi te naziv ide po godinama, drugi po zaslugama, treći po vjeri, posljednji po ljubavi - slušaj $[\ldots] . \ll^{38}$

Od žena je tražio poniznost, i to posebno od onih koje su se predale na služenje Gospodinu u monaškom životu. Znao je pisati o oholim i licemjernim monahinjama:

»Takove, čim koga spaze, uzdišu, spuštaju obrve, i pokrivši lice, jedva ostave nepokriveno jedno oko da mogu vidjeti. Na njima je crna haljina, pojas od kostrijeti, a ruke su im i noge nečiste; samo u trbuhu, jer se ne može vidjeti, vri im jelo. Za njih se svaki dan pjeva onaj psalam: 'Gospodin će razbacati kosti ljudi koji su sami sobom zadovoljni'. Druge, preobučene u muško odijelo, stide se biti ženske glave kako su stvorene, strigu kosu, besramno uspravljuju lice s koga nalikuju na uškopljenike. Ima ih koje se preoblače u kostrijet, i umjetno načinivši sebi kukuljice, da se vrate na djetinju, nalikuju na ćukove i sove. $\ll^{39}$

\footnotetext{
${ }^{36}$ Isto, XXII, 7: PL 22, 398.

${ }^{37}$ Isto, XXII, 16: PL 22, 404.

${ }^{38}$ Isto, XXII, 26: PL 22, 412. U latinskom izvorniku stoji pojam caritas, tako da bi se moglo reći da Eustohiju krasi djelotvorna ljubav.

${ }^{39}$ Isto, XXII, 27: PL 22, 413.
} 


\subsection{DRUŽENJE SA ŽENAMA}

U prijateljskom raspoloženju piše Azeli o onome što drugi o njemu govore. Neki su govorili da je Jeronim sramotan, podmukao, varalica, neki su podrugljivo govorili o njegovu hodu i smijanju, drugi su se rugali njegovu licu, a neki opet prebirahu u pričama o njegovoj prostoti, a neki opet da je zločinac i ogrezao u svakoj opačini. Sam svjedoči da se često oko njega nalazilo mnoštvo djevica; nekima od njih tumačio je Sveto pismo, nekima je predavao, a to je prouzročilo poznanstvo, a od poznanstva se rodilo pouzdanje. Nastajale su i klevete o njegovu druženju sa ženama. Veli da ga kore samo zato što je muško i samo zato što je Paula zaželjela ići s njim u Jeruzalem. Čak je i sud vodio protiv klevetnika, dobio je sud, ali ostale su i dalje neugodne priče. Lijepo kaže da ga je sav Rim volio, cijenio, poštovao, smatrao ga dostojnim vrhovnoga svećeništva, držali su ga poniznim, svetim, rječitim, papa Damaz mu je svjedok. Toga dana kad je ušao u Paulininu kuću sve su ga krjeposti napustile. Postao je meta drugima. Kao odgovor svim pričama koje su kružile uokolo pisao je prijateljici Azeli:

>Između rimskih gospođa ne nađe se ni jedna da mi osvoji srce do one koja je u tuzi, koja posti, koja je prljava i kaljava, koja je od plakanja na po oslijepila, koja se cijele noći moli milosrđu Božjemu, tako da je sunce često puta zateče na molitvi; kojoj su pjesme psalmi, razgovori Evanđelje, slasti uzdržljivost, življenje post: ni jedna ne mogaše mi omiljeti osim one koju nikad ne vidjeh da jede. $\ll^{40}$

To je slušao i s tim se borio gotovo tri godine, a na sve je mogao samo nadodati da ga je Gospodin čuvao kao i njih za zadnji sud. Unatoč svim pričama Jeronim završava pismo, prije nego se ukrcao na brod u ljeto 385. godine, ovako: »Pozdravi Paulu i Eustohiju, u Isusu Kristu moje, bilo to drago ili mrsko svijetu. Pozdravi mi mater Albinu i sestru Marcelu, i Marcelinu sa svetom Felicitom; i reci im da ćemo u isto vrijeme izaći na sud pred Isusa Krista: ondje će se vidjeti kakav je tko u srcu bio. $\ll^{41}$

\subsection{Hrabrost I SVETOST ŽENE}

Jeronim se susreo sa smrću prijateljice Paule i tom prigodom napisao je pogrebnu besjedu u kojoj na malo podulji način iznosi o njezinu životu. Paula je živjela krjepostan i svet život, kao vrhunac nasljedovanja Krista bio je njezin odlazak s kćeri Eustohijom u Svetu Zemlju 385. godine. Prije odlaska upoznala je crkvene osobe (biskupe!) koje su je ohrabrile da napusti posjete uglednih i slavnih osoba i da krene u svetu Zemlju. Njezin odlazak Jeronim opisuje na sljedeći način:

\footnotetext{
${ }^{40}$ Pismo Azeli, XLV, 3: PL 22, 481.

${ }^{41}$ Isto, XLV, 7: PL 22, 484.
} 
»Ohrabrivši se njihovim krepostima svaki čas je mislila napustiti domovinu. Ne sjećajući se kuće, djece, obitelji, imovine, niti ikakve stvari na svijetu, željela je poći sama i, ako se može reći, bez pratnje u pustinju Antonijevu i Pavlovu. Pa najzad, kad minu zima, i bi slobodno putovanje po moru, te se biskupi vraćahu svojim crkvama, željom i sam otplovi s njima. (...) Sađe u luku, prateći je brat, rodbina, svojta i, štoviše, njezina djeca, željna da sinovskom ljubavlju osvoje preljubežljivu majku. (... ) Mali Toksocije (sin!) na obali, moleći pružaše ručice; a Rufinu, već djevojka za udaju, ne progovarajući, moljaše suzama da počeka do njezina vjenčanja. Pri svem tome, ne pustiv ni suze, ona podizaše oči k nebu, ljubavlju prema Bogu, nadvlađujući ljubav prema djeci. $\ll^{42}$

Ističe se ljubav prema Bogu na prvome mjestu, zatim ljubav prema savjetu crkvenih osoba da krene na put, a tek onda ljubav prema vlastitoj obitelji i djeci. Za svetoga Jeronima ljubav žene, majke Paule za nasljedovanjem Krista u monaškom i pustinjačkom životu ima prednost pred ljubavlju prema rođenoj djeci. Ostavlja djecu da bi nasljedovala Krista. Nema sumnje, za Jeronima je to hrabrost i svetost koju je pronašao kod prijateljice Paule.

\section{Zaključak}

U rad smo uključili 18 pisama. Ukupno ih ima 154, a podijeljena su u pet skupina. Nastajala su u razdoblju od 370. do 420. godine u pustinji, Rimu i Betlehemu.

Pisma su pisana u različitim prilikama, za različite osobe, s različitim porukama. Bez obzira na rečeno ona u sebi sadrže jedan neposredan stil. Neka su po svom sadržaju napisana kao odgovor na postavljena pitanja, neka su gotovo kao traktat jer izlažu naširoko pojedine teme: djevičanstvo, udovištvo, monaški život, klerički život, odgoj djevojaka, nadgrobni govori. Kroz povijest su ta pisma bila vrlo cijenjena, prepisivana i tiskana, čitana i kritički analizirana te na taj način vrjednovana. Pisana su konkretnim osobama, ali neizravno su upućena i Jeronimovim suvremenicima jer su po svom sadržaju i kršćanskoj poruci pisma postala duhovno i biblijsko blago. U njima se krije blago ljudske intime i baš su zato privlačna i prepoznatljiva svima.

Jeronim neizravno piše o sebi, a neposredno o drugima. On je prijatelj svima, ili barem to želi biti, i zato mnogo piše o prijateljstvu. Prijateljstvo se dugo traži, a kad ga se nađe potrebno je mnogo truda da ga se očuva, ali ono čovjeka i lomi. Uistinu, kod Jeronima se pronalazi oznaka prijateljstva: snažno i lomljivo. Držao je do svojih prijatelja, do osoba koje su mu nešto značile, to ga je nosilo, ali kad je prijateljstvo prekinuto, pretvorilo ga je u neprijatelja.

${ }^{42}$ Pogrebna besjeda svetoj Pavli, CVIII, 6: PL 22, 881. 
Otkrivamo da su i Jeronimovi suvremenici govorili i pisali o njemu, u njemu su promatrali prijatelja i duhovno-intelektualni oslonac. Sveti Augustin cijenio je Jeronimovu sposobnost pisanja s lakoćom, isticao je njegovo izvrsno poznavanje poganske klasične literature, s poštovanjem je priznavao njegovo poznavanje Svetoga pisma. Rufin je u njemu vidio duhovnu i intelektualnu moć, kao i mnogi drugi crkveni ljudi i monasi, monahinje i laici, ali to ga nije sprječavalo da svima njima u pisanom obliku izgovori oštre i nimalo ugodne riječi. A kada je uočio manjkavosti, bez obzira na to o kome je riječ, isticao je njihovo intelektualno, duhovno i moralno zastranjenje. Tražio je istinu i samo istinu, a tražeći istinu »izgubio « je prijatelje. Tako je prijateljski Jeronim postao neprijatelj mnogima, ali ne i Bogu.

Kršćanske poruke koje smo istaknuli u ovom radu ponajprije se tiču same Crkve i njezina poslanja. Sveti Jeronim pristupao je Riječi Božjoj sa strahopoštovanjem, bio je iskustveno svjestan da poznavati pisanu Božju Riječ vodi poznavanju samoga Boga. Na taj način čovjek bolje upoznaje samoga sebe. Služeći Božjoj Riječi, postiže se kršćanska i osobna zrelost, kao i zajedništvo s Bogom. O dostojanstvu reda prezbiterata Crkva je uvijek osjećala potrebu rasprave sa svojim i o svojim službenicima, od samih početaka pa do danas. Obnova Crkve uvelike je ovisila o takvim raspravama. Dostojanstvo žene vrijednost je koja se i u Jeronimovo vrijeme nametala kao vrijednost koju je trebalo cijeniti i prenositi, barem unutar kršćanske zajednice.

Svećeniku Nepocijanu napisao je da nitko drage volje ne pripovijeda onomu koji preko volje sluša. Prašina povijesti nije prekrila lik i djelo sv. Jeronima, štoviše, od njegove smrti 420. godine pa do danas u njemu prepoznaše potencijalnog prijatelja i sugovornika umjetnici i arhitekti, književnici i znanstvenici, teolozi i bibličari, crkveni službenici i laici, muškarci i žene. Svatko je iz svoga kuta gledišta i zanimanja doprinosio stvaranju portreta sv. Jeronima, svatko je od njih svojim uhom osluškivao uvijek aktualni jeronimovski duh, a tom portretiranju sveca i grješnika Jeronima pridružuje se i ovaj članak o kršćanskim porukama. 


\section{CHRISTIAN MESSAGES IN THE LETTERS OF ST. JEROME}

\section{Drago TUKARA*}

Summary: This article was written on the occasion of the $1600^{\text {th }}$ anniversary of the death of St. Jerome, and it deals with Jerome's letters, that is, some Christian messages in those letters. In the first part, the saint places emphasis on building one's own personality and relationship with God. As a lover of Sacred Scripture, Jerome confesses before God; he encounters God within himself and in the interpretation of Scripture, and all those who are lazy to know God and the mystery of the Word are subjected to his criticism. The second part of the paper deals with emphasizing mutual cooperation within the church community, primarily among priests, deacons, monks. In this context, the value of friendship and peacekeeping among church officials is an overriding topic for Jerome. The third part is dedicated to the dignity and role of women. The fact is that Jerome's life and work are marked by communication with women. These are primarily widows, nuns, girls, mothers, wives, rich and respectable Roman citizens. The author wishes to point out that all of Jerome's correspondents, directly or indirectly, clearly or dimly, mirror the mentioned Christian messages.

Keywords: God, St. Jerome, letters, Christian messages, church officials, women.

* Asst. Prof. Drago Tukara, Ph. D., Catholic Faculty of Theology in Đakovo, J. J. Strossmayer University of Osijek, Petra Preradovića 17, P. O. box 54, 31400 Đakovo, Croatia, drago.tukara@gmail.com 